\title{
Implementation of school rules to improve the teachers and student discipline
}

\author{
Wanda Wanda ${ }^{1}$, Syarwani Ahmad ${ }^{2}$, Yessi Fitriani ${ }^{2}$ \\ ${ }^{1}$ Sekolah Menengah Atas Negeri 16 OKU, Indonesia \\ ${ }^{2}$ Universitas PGRI Palembang, Indonesia
}

\section{Article Info}

\section{Article history:}

Received Jul $7^{\text {th }}, 2021$

Revised Aug $22^{\text {th }}, 2021$

Accepted Aug 30 $0^{\text {th }}, 2021$

\section{Keyword:}

Implementation of School Rules Teacher Discipline Student Discipline

\begin{abstract}
This research is motivated by the existence of disciplinary violations committed by teachers and students at SMA Negeri 16 OKU. This happens because there are still obstacles that hinder the process of implementing the value of discipline in increasing teacher and student compliance with the rules of law in SMA Negeri 16 OKU. This study aims to determine the implementation of school discipline in improving the discipline of teachers and students in SMA Negeri 16 OKU. This research uses descriptive methods and qualitative approaches. Data collection techniques in this study include: interviews, observation and documentation. Research Results Broadly speaking, the existing regulations are able to make teachers and students at SMA Negeri 16 OKU become more disciplined. For example, for students who are late, SMA Negeri 16 OKU requires students to ask for a permit from the picket teacher. Many high school students (SMA) are not disciplined. This is a consequence of adolescence, where students violate applicable norms, such as: rampant student brawls, truant students, criminal acts, and drug and drug abuse. However, if this educational institution is properly managed and organized in such a way, especially in consistently applying school rules to students, it will create an educational situation or climate that is conducive to disciplined personal development of students.
\end{abstract}

(C) 2021 The Authors. Published by IICET

This is an open access article under the CC BY-NC-SA license

(https://creativecommons.org/licenses/by-nc-sa/4.0

\section{Corresponding Author:}

Wanda, W.,

Sekolah Menengah Atas Negeri 16 OKU, Indonesia

Email: Wanda.oku@gmail.com

\section{Introduction}

Our world of education today faces a number of very complex problems and needs special attention for all of us. One of these problems is the decline in social life norms and moral ethics in the practice of life at school which results in a number of negative behavior of students which is quite disturbing for the community. This includes the increasing number of deviations from various norms of religious and social life in society [1].

In response to this, it is necessary to have a means that can limit or direct students so that their actions do not violate norms so that educational goals can be achieved. To achieve optimal educational goals, an atmosphere that supports the teaching and learning process and personal development is needed. In life together, this can be formed by the existence of rules of living together called order.

The implementation of school rules has two very important functions in helping to familiarize children with controlling and curbing desired behavior, as suggested by Hurlock, namely: first, regulations have educational value and second, regulations help curb unwanted behavior, while violations of discipline is a 
form of student delinquency which is done according to their own will regardless of the rules that have been made [2]

Students who are not disciplined or violating school rules will affect their learning. Discipline must be cultivated in the hearts of children so that they have a means of self-control. Without the effort to instill discipline in children, it is very unlikely that the success of education will be achieved because of the interference and obstacles to student learning activities in their behavior. According to Oteng Sutisno, school discipline is an effort that is consciously directed and organized in order to carry out the assigned tasks and can be accounted for in accordance with the abilities it has, this effort is realized to create school efficiency and achieve good educational goals [3].

[4] school rules are a number of regulations that must be obeyed or implemented in schools so that the teaching and learning process can take place smoothly. The rules are made to be obeyed by students, while schools are educational institutions that carry out a teaching and learning process [4]

[5] rules, both general and specific, include three elements. namely: 1) obligatory and prohibited actions or behavior, 2) consequences or sanctions that are the responsibility of the rule breaker, and 3) methods or procedures for conveying regulations to subjects subject to the school rules. School rules are made so that students and teachers know their duties, rights, and obligations, know what is allowed and their activities increase and avoid problems that can complicate them, and so that students know and carry out properly all the activities that have been programmed. by schools both intracurricular and extracurricular activities. Therefore, student obedience to school discipline is the main goal of education.

School rules are made with the following objectives:1) So that students know their duties, rights, and obligations. 2) So that students know what is allowed and increase creativity and avoid problems that can make it difficult for them. 3) So that students know and carry out well all activities that have been programmed by the school both intracurricular and extracurricular [6]

The teacher's role is very important in carrying out learning and administering class and school administration. Without good performance from a teacher, the learning carried out will not produce something useful and useful so that students will be left behind by the progress and demands of the everchanging society. In simple terms, it can be said that teacher performance means that there are competencies shown in the form of behaviors that can complete work on time (efficiency), are creative, innovative and are responsible for completing their work [9.]

With the discipline in schools, students get used to being kind and obedient to the applicable rules so that there are no more violations in the school. Therefore, schools must consistently carry out discipline from both teachers and students so that they can improve the quality of student behavior [7].

SMA Negeri 16 OKU has been established since 2011 and has undergone four school principal changes. The total number of teaching staff is 27 people, with details of 5 civil servants and 22 non-permanent teachers, 2 educational staff with non civil servant status. With the number of teachers who are mostly non-permanent employees, the teachers in these schools have a double job not only teaching in one school but teaching in several schools so that the attendance of some teachers in schools is quite minimal and some teachers who live in the city center also sometimes had to arrive late to school because the city to school was almost two hours away.

There are 203 students at SMA Negeri 16 OKU for the 2019-2020 school year with details, for class XII totaling 66 students, class XI totaling 62 people and class X totaling 75 people. The environment of students who mostly come from rural areas, with the economic background of their parents who are mostly farmers and traders, so that sometimes this is the reason for students to come late because they have to travel quite a distance to school and are not dressed according to the regulations. which has been determined by the school, such as not wearing a toe shirt and wearing sandals at school because of the economic condition of the parents who can be categorized as underprivileged.

Based on this background, the author is interested in researching directly on "Implementation of School Rules in Improving Teacher and Student Discipline". Through this research, it is hoped that it can be an input to improve the quality of education at SMA Negeri $16 \mathrm{OKU}$ for the better. With the formulation of the problem, how is the implementation of school rules in improving the discipline of teachers and students at SMA Negeri 16 OKU? The purpose of this study is to determine the implementation of school discipline in improving the discipline of teachers and students in SMA Negeri 16 OKU. 


\section{Method}

Based on the research focus that has been determined, the type of research used in this study is qualitative research. [5] states that qualitative research is research that investigates surrounding problems and then presents the results of the research according to the actual situation. This type of research is descriptive qualitative research that studies the existing problems and working procedures. This descriptive qualitative research aims to describe, record, analyze and interpret conditions that currently occur or exist. So this research procedure, will produce descriptive data, in the form of written or spoken words from people and observable behavior. This qualitative descriptive study aims to describe a situation or phenomenon as it is.

This research was conducted at SMA Negeri 16 OKU which is located at Jalan Simpang Tanjung Lengkayap KM, 14 Tualang Village, Lengkiti District, Ogan Komering Ulu Regency. The researcher chose this location because the school is located far from the city center, which is in a village that still upholds customs and manners. In this school, there are rules in the form of student regulations and teacher rules that are made in the form of documents, but even though the rules have been made by the school, in reality, the implementation is still not optimal, because there are still some students who then violate the rules that have been made and some teachers who are still less disciplined in teaching. Therefore, researchers are interested in examining this matter further..

Basically, qualitative data collection techniques are tentative, because their use is determined by the context of the problem and the description of the data obtained. In every data collection process, there must be techniques used in accordance with the acquisition carried out. To capture the data needed in the study, the authors use observation, interview and documentation techniques. Observation is a technique or a way of collecting data by observing ongoing activities. Because the object of this research is the principal, teachers, staff and students, the writer will make direct observations on how the school discipline is implemented and its impact on teachers and students of SMA Negeri 16 OKU. These observations will last as long as the research is conducted.

Interviewing is a conversational process with the intention of constructing people, events, organizations, motivations, feelings, and so on, which is carried out by two parties, namely the interviewer who asks questions with the interviewee [8]. The people who will be interviewed are referred to in this case, namely the Principal, Teachers, Staff and Students of SMA Negeri 16 OKU. The author tries to dig up information by asking some questions to informants to find out the existing practices in the field related to the implementation of school rules and discipline of teachers and students in SMA Negeri 16 OKU.

Documentation is looking for data about things or variables in the form of notes, transcripts, books, newspapers, meeting minutes, leggers, agendas and so on [5]. For this research, it is done by reviewing documents related to the object of research

\section{Results and Discussions}

Research on the implementation of school regulations in improving teacher and student discipline provides strengthening of the implementation of school discipline which is carried out at SMA Negeri 16 OKU in the 2020/2021 school year. The research was carried out in October to December 2020 which included observation, namely to collect data carried out by conducting direct observations in the field, interviews to ask questions orally to data sources consisting of the principal, vice principal and teachers with interview guidelines which has been submitted, the documentation is to obtain data about school profiles and data about teachers and students at SMA Negeri 16 OKU.

The rules at SMA Negeri 16 OKU are a collection of rules that govern what must be done and what should not be done while in the school environment and these rules must be obeyed by all school members. According to the explanation of Mrs. "SA" as the Principal of SMA Negeri 16 OKU that the existing regulations in SMA Negeri 16 OKU can be said to be quite optimal in their implementation, because everything that is planned has gone accordingly. As for several things that have been done to improve the discipline of students of SMA Negeri 16 Oku, as follows: (a)Check uniform, nails and hair neatness (b)Checking the contents of the student's bag and luggage (c)Provide a counseling approach to students with problems (d)Inviting students to love environmental cleanliness by getting used to not littering (e)Developing extracurricular activities in schools( f)Inviting students to worship activities such as reading Surah Yasin every Friday morning

Regarding the arrival of students with these rules it is supported by the existence of a student tardiness book. which contains the name of the student, as well as the reason for the delay which will be filled in by the 
picket teacher. In addition, there is also a class entry permit card that has been prepared by students and can be requested at the picket teacher. As for student violations in addition to violations of late arrival to school, there were other violations which were then recorded in the student incident book

In terms of uniforms at school, the school also has rules that have been socialized to both students and guardians. Researchers found that some students did not wear shoes when going to school, but instead used footwear in the form of sandals. In addition, the researchers also found that some students did not use attributes such as ties and names. Some students who violated were then given a warning from the picket teacher.

SMA Negeri 16 OKU conducts an evaluation every 1 year on the rules that have been planned and implemented for a year. This is done to be able to find out the success rate of the rules that have been applied to both teachers and students and to correct deficiencies that have not been maximal in their implementation so far.

Based on the results of interviews with school principals and teachers, it can be concluded that the rules imposed at SMA Negeri 16 OKU are guidelines for every school member in carrying out their obligations both as teachers and students and regulating how to behave and behave in accordance with daily manners and manners. days, the school discipline evaluation is carried out once a year, namely before the admission of new students by inviting the vice principal, counseling teacher, homeroom teacher and student council supervisor and the school committee. Then discuss everything that is a complaint or suggestion in order to fix anything that is not right.

This form of evaluation is carried out in school meetings attended by school principals, deputy principals, teachers and school committees to discuss programs that have been running for one year and find solutions to what have been obstacles in the implementation of these rules so far. Usually the evaluation meeting is held before the admission of new students, and the results of the discussion will be disseminated to teachers, staff, guardians and new students as well as students of class XI and XII. With the discussion about school rules, it is hoped that SMA Negeri 16 OKU will have school rules that are in accordance with the conditions of the school.

Each homeroom teacher and subject teacher has data on every student who has problems with student discipline, both inside and outside the classroom. Furthermore, every student who violates is given sanctions from the homeroom teacher according to his violation. If it is heavy and frequent, the counseling guidance teacher will provide guidance to these students. The school principal always evaluates everything that has been implemented in the school, especially matters of discipline such as reprimanding every teacher who arrives late and imposing sanctions for those who violate it. With evaluation, we can assess and fix things that are considered less than optimal in order to achieve the expected goals.

Based on the results of the interview above, it can be said that the school rules at SMA Negeri 16 OKU have been carried out well, this can also be strengthened by the results of field research observations that SMA Negeri 16 OKU evaluates the implementation of school rules once a year, namely before admission new students by involving many parties such as deputy principals, counseling teachers, homeroom teachers, student council coaches and school committees.

Efforts that have been made by SMA Negeri 16 OKU in applying discipline to students based on the results of interviews with teacher informants and school principals show that the efforts made to prevent students from violating school rules such as providing direction and socialization of discipline to students both during the Orientation Period Students flag ceremonies and while in class by their respective teachers and homeroom teachers, as well as in extracurricular activities. In addition to socialization in every activity, several other efforts were also made such as providing motivation and advice to students by constantly reminding students to behave in discipline while in school, being given a warning in the form of a warning every time they meet a student who violates, calling and gathering students who violate by the student section, be monitored during class, provide written warnings, and provide penalties according to the type of violation.

For obstacles in implementing discipline for teachers, it is felt that it does not really affect it because every teacher already knows and understands what is the discipline in the school and also the principal always discusses it both during guidance meetings and at ceremonies. For obstacles in implementing discipline for teachers, it is felt that it does not really affect it because every teacher already knows and understands what is the discipline in the school and also the principal always discusses it both during guidance meetings and at ceremonies.

In implementing school regulations at SMA Negeri $16 \mathrm{OKU}$, there are obstacles faced that can affect the success or failure of student discipline to improve student discipline, as follows: 


\section{Internal factors}

Lack of teacher consistency in enforcing class rules

It can be seen from the narrative of the mother "VA" that during this time she had indeed missed school several times because her child was sick. In this case, he received a warning from the principal for neglecting his duties and responsibilities at school so that the class that previously received lessons from Mrs. "VA" became empty and some students left the classroom without permission from the picket teacher. This is in line with the narrative of some students, who said that when hours are empty without a teacher, sometimes the class becomes noisy and some students leave the classroom and indeed for minor disciplinary violations, students sometimes do not get a reprimand from the teacher.

\section{Student character}

The character of high school students who are difficult to organize and like to chat is difficult to keep quiet in class. At SMA Negeri 16 OKU, several teachers said, especially for male students. Where they are more active and harder to tell. Sometimes students are difficult to ask to be calm, so teachers have to be even more creative in implementing teaching and learning activities

Lack of coordination, so that information often stops in class.

In this case, the expected coordination is coordination between the homeroom teacher and representatives of the student sector. Even though the homeroom teacher is given the authority to solve problems in his class while teaching, students also hope that this is still communicated with students. So that students can also help in solving problems if the problem cannot be resolved.

Time, in terms of mentoring and observing students

In SMA Negeri $16 \mathrm{OKU}$, the mentoring time for students can only be done when the students are in school. Meanwhile, students' time in school is only about 6 to 8 hours. The rest of the students are in the home and family environment. So that in this case the teacher is not able to fully provide supervision, assistance and observation of all student activities as a whole. So that this becomes one of the factors of the constraints to maximize student discipline

\section{Extrenal factors}

Lack of support and participation from parents in enforcing rules

The support and participation of parents in improving student discipline is needed. However, at SMA Negeri $16 \mathrm{OKU}$, there are still some student guardians who don't care. As in the case of students who do not attend school without a notification letter, on the grounds that the student is unable to come to school because they are sick but they do not send a letter as evidence that the student is indeed sick. In addition, there are some student guardians who have even been called to come to school for reprimands and are still repeating this. Because although this student's absence and tardiness in any school is bound to happen, this should not be tolerated. Because it can interfere with the teaching and learning process and student readiness.

The distance from the residence to the school is quite far

Due to the distance, it turned out that there were some students whose houses were quite far away. Make some students often late. In this case several times the school has given a warning, but it is still being repeated.

\section{Conclusions}

Based on the results of the research findings, it can be concluded that in the compilation of regulations at SMA Negeri 16 OKU which is carried out by involving all elements of the school including the vice principal, counseling guidance teacher, homeroom teacher, student council supervisor and school committee, routine socialization, and educational sanctions for student or female offender. Broadly speaking, the existing regulations are able to make teachers and students at SMA Negeri 16 OKU more disciplined. For example, for students who are late, SMA Negeri 16 OKU requires students to ask for a permit from the picket teacher, in violation of uniforms and students who are still out and about when teaching and learning activities, first students will be given a warning, if it recurs, the school will take other actions. Likewise, teachers who commit violations will be given sanctions in the form of reprimands or in writing. It is hoped that the principal will be able to provide motivation and be able to act decisively so that the rules can provide an optimal role in improving the discipline of teachers and students in schools and for teachers to be able to set an example in the form of discipline to obey the rules and always work on time so that they can become role models for their students in school 


\section{References}

Baharuddin. (2009). Pendidikan dan Psikologi Perkembangan. Yogyakarta: ArRuzz Media

Irwansa, A., Muh. Arsyad Maf'ul. (2015). "Analisis Pelaksanaan Tata Tertib Sekolah Pada Siswa di SMK Negeri 1 Makassar," Jurnal Tomalebbi II, no. 1-13

Sutrisno, Hadi. (1983). Metodologi Researc. Yogyakarta: Yayasan Penerbit FKLTS Psikologi UGM.

Habsari, Sri Dra. (2005). Bimbingan Dan Konseling SMA. Jakarta: Grasindo

Arikunto, Suharsimi. (1990). Manajemen Pengajaran Secara Manusiawi, Jakarta: Rineka Cipta

Rifa'I, Muhammad. (2011). Sosiologi Pendidikan. Yogyakarta: AR-Ruzz Media

Berutu, E. Y., Ely, R., \& Yusuf, M. N. (2018). Implementasi Tata Tertib Sekolah Dalam Membentuk Kedisiplinan Siswa Sekolah Dasar Negeri Gue Gajah Aceh Besar. Jurnal Ilmiah Mahasiswa Pendidikan Guru Sekolah Dasar, 3(2).

Bungin, Burhan. (2008). Penelitian Kualitatif. Jakarta: Kencana Prenada Media Group.

Herry, H., Lian, B., \& Fitriani, Y. (2020). Pengaruh Kepemimpinan Kepala Sekolah dan Komitmen Guru terhadap Kinerja Profesional Guru. Jurnal Pendidikan Tambusai, 4(2), 1658-1666. 